\title{
Screening of Wilson's disease in a psychiatric population: difficulties and pitfalls. A preliminary study
}

Caroline Demily ${ }^{1,3^{*}}$, François Parant ${ }^{8}$, David Cheillan², Emmanuel Broussolle ${ }^{3,4}$, Alice Pavec ${ }^{5}$, Olivier Guillaud ${ }^{3,6}$, Lioara Restier ${ }^{3,7}$, MOPSY Consortium, Alain Lachaux ${ }^{3,7}$ and Muriel Bost ${ }^{2,3,8}$

\begin{abstract}
Background: Wilson's disease (WD) is a rare autosomal-recessive, inherited disorder caused by a mutation in the copper-transporting gene ATP7B affecting the liver and nervous system. About 30\% of patients with WD may initially present with psychiatric symptoms, and diagnosis can be difficult to establish. The objectives of the present preliminary study were [1] to evaluate the relevance of serum copper (Cu) and ceruloplasmin (Cp) measures in hospitalized patients with psychiatric disorders; and [2] to identify possible mutations in the ATP7B gene in patients with abnormal biological copper profile.
\end{abstract}

Methods: All psychiatric patients who participated in this study were hospitalized in Saint-Jean de Dieu Hospital (Lyon, France). Cp was measured by immunoturbidimetry and serum Cu by inductively coupled plasma-optical emission spectrometry. When Cp and serum Cu levels were inferior to, respectively, $0.18 \mathrm{~g} / \mathrm{L}$ and $0.88 \mathrm{mg} / \mathrm{L}$ in combination with atypical psychiatric presentations, complete clinical examinations were performed by multidisciplinary physicians specialized in WD. In addition, mutation detection in the ATP7B gene was performed.

Results: A total of 269 patients completed the study. (1) 51 cases (19\%) showed both decreased Cp and Cu concentrations. (2) Molecular genetic tests were performed in 29 patients, and one ATP7B mutation (heterozygous state) was found in four patients. We identified three different missense mutations: p.His1069Gln, c.3207C >A (exon 14), p.Pro1379Ser, c.4135C>T (exon 21) and p.Thr1434Met, c.4301C>T (exon 21). No pathogenic mutation on either ATP7B allele was detected.

Conclusion: Results of $\mathrm{Cp}$ and/or serum Cu concentrations below the normal limits are common in patients with psychiatric disorders and nonrelevant and/or informative for the WD diagnosis. WD diagnosis is based on a combination of clinical and biological arguments. Psychiatric patients with suspicion of WD should be evaluated in a reference center.

Trial registration CPP Lyon Sud-Est IVNo 10/044, CNIL No DR-2011-470, Afssaps No B100832-40 and CCTIRS No 10.612 bis, registered 8 June 2010

Keywords: Serum copper, Ceruloplasmin, ATP7B gene, Wilson's disease, Psychiatric disorders, Inborn errors of metabolism, Treatable hereditary metabolic disorders, Copper homeostasis, Copper chelators, Schizophrenia, Bipolar disorders, Alcohol abuse, Mental health, Mental diseases, Etiopathogenesis

\footnotetext{
*Correspondence: caroline.demily@ch-le-vinatier.fr

${ }^{\wedge}$ Deceased

1 GénoPsy, Center for the Detection and Management of Psychiatric

Disorders of Genetic Origin, Pôle Ouest, Hôpital le Vinatier \& UMR 5229

(CNRS \& Lyon University), 95 Bld Pinel, 69677 Bron cedex, France

Full list of author information is available at the end of the article
} 


\section{Background}

Wilson's disease (WD, MIM\#27790) is an inherited, autosomal-recessive disorder of copper metabolism. It is caused by mutations in the ATP7B gene (MIM\#606882), which is located on chromosome 13 [1] and encodes for a membrane copper-transporting ATPase, ATP7B (NM 000053.3). The protein is located on the Golgi membrane and is involved in copper transport across cell membranes. The prevalence of WD is estimated as one in 30,000 in most populations with a carrier frequency of one in 90 [2], but a recent study of abnormal gene frequency points to a possible higher prevalence of $1 / 7026$ [3]. The disease is fatal unless treated by effective medication such as chelators and zinc salts [4]. The initial clinical manifestations are mainly hepatic ( $40 \%$ of cases), neurological (35\%), and psychiatric (10\%). Hematologic, renal, or ocular (15\%) manifestations may also be associated $[5,6]$. According to case series, up to one-third of the WD patients may initially present with behavioral or psychiatric abnormalities [7].

When psychiatric manifestations are isolated, WD diagnosis is difficult to establish. Brain magnetic resonance imaging may be normal [8], and Kayser-Fleischer ring may be absent in many psychiatric presentations [9]. WD diagnosis is often delayed when psychiatric symptoms preceded neurological or hepatic involvement [10]. About $20 \%$ of patients commonly undergo psychiatric treatment before specific chelation therapy [11, 12]. A wide set of psychiatric, psychological, and psychosocial impairments have been reported. These include intellectual deficiency, confusion, cognitive impairment, dementia, poor scholar performance, anxiety, depression, emotional lability, mania, behavioral abnormalities and personality disorders, schizophrenia-like states, and suicide. A retrospective analysis of patients with various hereditary metabolic disorders including WD showed that psychiatric signs may remain isolated for years before other more specific organic signs appear [13].

In WD patients, an early and accurate diagnosis is the key to effective disease management (refer patients to a reference center; initiate chelator therapy in order to prevent irreversible complications; and provide genetic counseling to the patients and their family). However, WD diagnosis still remains a challenge [14] because (a) care team does not think about this pathology, particularly in psychiatric unit; (b) diagnosis algorithms for WD are based on Leipzig score [15] using a broad combination of biochemical tests (serum ceruloplasmin, 24-h urinary copper excretion, serum-free copper, and hepatic copper), but most of them are difficult to apply to psychiatric patients.

Typically, the biological detection of WD is often based on ceruloplasmin ( $\mathrm{Cp}$ ) and serum copper (serum
$\mathrm{Cu}$ ) measurements (levels of $\mathrm{Cp}$ and serum $\mathrm{Cu}$ are usually abnormally low). If the results from these tests are abnormal or unclear, then they may be followed by a 24-h urinary copper test to measure copper elimination. In psychiatric patients, this procedure may be associated with practical difficulties, often with incomplete urinary sampling or times errors. The urinary copper/creatinine $(\mathrm{Cu} / \mathrm{Cr})$ ratio may be used in replacement.

The main objective of the present preliminary study was to assess the $\mathrm{Cp}$, serum $\mathrm{Cu}$, and urinary $\mathrm{Cu} / \mathrm{Cr}$ ratio determination in hospitalized patients with psychiatric disorders, in terms of feasibility and relevance. The second objective was to identify possible mutations in the $A T P 7 B$ gene in patients with abnormal biological copper profile.

\section{Methods}

Patients: psychiatric diagnosis interview, tools, and psychiatric assessment

The study protocol was approved by the competent French data-protection authority (CPP Lyon Sud-Est IVNo 10/044, CNIL No DR-2011-470, Afssaps No B100832-40 and CCTIRS No 10.612 bis), in compliance with French legislation. Written and informed consent was obtained from patients, and from parents or guardians of minors.

Patient inclusion in the study lasted 15 months. A total of three hundred and five patients (16-65 years old) hospitalized for various mental health disorders in SaintJean de Dieu Hospital (Lyon, France) were included. The recruitment included all patients (without specific clinical inclusion criteria) already hospitalized and newly admitted patients. Exclusion criteria were emergency conditions, inflammatory or tumoral diseases, and lack of consent. Pregnant women could be enrolled, but data were considered separately. The size of the population in this proof-of-concept study was not designed to provide answers regarding the prevalence of WD among hospitalized patients with psychiatric disorders (which is thought to be higher than that in the general population) [10] but was determined according to the challenge of performing laboratory tests with complete clinical and possible neurological and hepatic assessment in a large sample of hospitalized patients with psychiatric disorders; and the documented variabilities of $\mathrm{Cp}$ and serum $\mathrm{Cu}$ levels in the general hospitalized population $[16,17]$.

Two evaluators established consensus diagnoses according to ICD-10 criteria. The diagnosis was systematically assessed by two trained psychiatrists. They used all the information available from direct interviews of patients and examination of case notes. Symptoms were evaluated with M.I.N.I. semi-structured interviews [18]. Information about alcohol or substance abuse, 
psychiatric morbidity, and treatments was recorded. The patients who reported that they did not use substances were considered as nonusers. A clinical assessment was performed in order to disclose neurological or hepatic signs. Clinical and biological data were compiled into case vignettes, and diagnoses were made blind regardless of biological data.

\section{Study design}

The study is a descriptive and transversal study focusing on the serum $\mathrm{Cp}$ and $\mathrm{Cu}$ measures in a cohort of hospitalized patients with psychiatric disorders.

According to the literature in general population, $\mathrm{Cp}$ and $\mathrm{Cu}$ concentration values were classified into three categories $[19,20]$ :

- above $0.18 \mathrm{~g} / \mathrm{L}(\mathrm{Cp})$ and $0.88 \mathrm{mg} / \mathrm{L}$ (serum $\mathrm{Cu}$ ): normal values;

- between [0.10-0.18] g/L (Cp) and] 0.50-0.88] mg/L (serum $\mathrm{Cu}$ ): borderline values;

- lower or equal to $0.10 \mathrm{~g} / \mathrm{L}(\mathrm{Cp})$ and $0.50 \mathrm{mg} / \mathrm{L}$ (serum $\mathrm{Cu})$ : critical values.

When $\mathrm{Cp}$ and serum $\mathrm{Cu}$ levels were inferior, respectively, to $0.18 \mathrm{~g} / \mathrm{L}$ and $0.88 \mathrm{mg} / \mathrm{L}$ in combination with atypical psychiatric and/or hepatic presentations, complete clinical examinations were performed by a psychiatrist, a neurologist, and an hepatologist specialized in WD (National Reference Center for Wilson's disease, Hospices Civils de Lyon, France). Slit-lamp evaluation of the cornea for Kayser-Fleischer rings (copper deposits on the outer rim of the cornea) was performed by an experienced ophthalmologist. Urinary copper-to-creatinine ratio was also used for assessing the copper elimination. In addition, mutation detection in the $A T P 7 B$ gene was performed in a second blood sample.

\section{Ceruloplasmin and serum copper measurements and urinary copper-to-creatinine ratio}

Serum Cp was determined using Pentra 400 analyzer (Horiba) using an immunoturbidimetric assay (DAKO Polyclonal Rabbit Anti-Human Ceruloplasmin). The assay was calibrated using the Protein 1 Calibrator (Siemens) traceable to the ERM ${ }^{\circledR}$-DA470 (CRM 470) [21]. Between-runs imprecision ranged from $4.8 \% \mathrm{CV}$ (coefficient of variation) at $0.08 \mathrm{~g} / \mathrm{L}$ to $2.0 \% \mathrm{CV}$ at $0.33 \mathrm{~g} / \mathrm{L}$. The method accuracy was determined using ProBioQual Scheme samples (http://www.probioqual.com).

Serum and urinary $\mathrm{Cu}$ concentrations were measured using an inductively coupled plasma-optical emission spectrometer (Vistapro, Varian). Between-runs imprecision ranged from $9.7 \% \mathrm{CV}$ at $1 \mathrm{mg} / \mathrm{L}$ to $8.7 \% \mathrm{CV}$ at
$2.99 \mathrm{mg} / \mathrm{L}$. Urinary copper-to-creatinine ratios were determined in random urinal samples. External quality control was ensured through participation in the CTQ Proficiency Testing Scheme (https://www.inspq.qc.ca/ ctq/paqe/pci/description).

\section{Mutation detection in the ATP7B gene: sequencing and MLPA analysis}

Genomic DNA was extracted from $10 \mathrm{~mL}$ of EDTA anticoagulated blood using salt precipitation method (Nucleon BACC3 RPN 8512, GE Healthcare).

For mutation analysis, PCR amplification of the 21 exons and flanking regions of the $A T P 7 B$ gene was performed using intronic primer pairs and the PCR conditions previously described [22]. Bi-directional sequencing was performed on AB 3730 Genetic Analyser with dyetermination chemistry, using SeqScape software. Nucleotide changes were detected by comparing the sequence obtained in the chromatogram with the normal gene sequence (NM_000053.3; Homo sapiens chromosome 13 complete sequence).

Patients with one mutation in the $A T P 7 B$ gene were tested using MLPA assay (SALSA MLPA KIT Wilson disease, MRC-Holland).

Our laboratory participates in the EMQN, an European interlaboratory quality-control program for mutation detection in WD.

\section{Statistical analysis}

Statistical analysis was performed with MedCalc (version 12.3.0; MedCalc Software, Mariakerke, Belgium). Two-sample group comparisons of median values were assessed with Mann-Whitney test. Multiple-group comparisons were assessed with Kruskal-Wallis test. A value of $p<0.05$ was considered as statistically significant.

\section{Results}

\section{Demographic and clinical data}

From the population of 305 patients initially included, a total of 269 patients completed the study (mean age of $41 \pm 22$ years, 118 females and 151 males). Thirty-six patients were excluded from the study because of missing data.

The following ICD-10 diagnoses were observed: schizophrenia $(n=116)$, bipolar disorders $(n=37)$, alcohol abuse $(n=37)$, depressive and/or anxiety disorders $(n=27)$, behavioral or personality disorders $(n=27)$, intellectual disability $(n=7)$, autism $(n=5)$, anorexia nervosa $(n=2)$, cannabis addiction $(n=4)$, and miscellaneous neurological disorders $(n=7)$.

All patients received psychotropic treatment (monotherapy or combination therapy): 
- antipsychotics $(n=210)$ : olanzapine $(n=63)$, risperidone $(n=33)$, aripiprazole $(n=23)$, cyamemazine $(n=27)$, haloperidol $(n=16)$, clozapine $(n=17)$, loxapine $(n=15)$, and other antipsychotic drugs $(n=16)$.

- anticonvulsants $(n=49)$ : valproate $(n=32)$, gabapentin $(n=9)$, clonazepam $(n=6)$, and carbamazepine $(n=2)$;

- antidepressants $(n=46)$ : escitalopram $(n=25)$, paroxetine $(n=8)$, venlafaxine $(n=6)$, agomelatine $(n=6)$, and fluoxetine $(n=1)$;

- lithium $(n=14)$.

Other non-psychotropic temporary treatments were not mentioned.

\section{Serum ceruloplasmin and copper determination}

Serum $\mathrm{Cp}$ and $\mathrm{Cu}$ levels were measured in all the 269 patients.

Median serum concentration was $0.21 \mathrm{~g} / \mathrm{L}$ (interquartile range [IQR] 0.18-0.25) for $\mathrm{Cp}$ and $1.02 \mathrm{mg} / \mathrm{L}$ (IQR $0.88-1.17)$ for $\mathrm{Cu}$.

\section{Intergroup comparisons \\ Gender}

Serum Cp concentrations were significantly lower in male (median 0.20, IQR 0.16-0.23 g/L) than those in nonpregnant female patients (median 0.23, IQR 0.20$0.26 \mathrm{~g} / \mathrm{L}$ ). Similarly, Cu concentrations were significantly lower in male (median 0.93, IQR $0.80-1.12 \mathrm{mg} / \mathrm{L}$ ) than in female patients (median 1.08, IQR $0.96-1.27 \mathrm{mg} / \mathrm{L}$ ) (all $p<0.0001$ ). In a pregnant woman, serum $\mathrm{Cp}$ concentration was $0.42 \mathrm{~g} / \mathrm{L}$ and $\mathrm{Cu}$ concentration was $1.89 \mathrm{mg} / \mathrm{L}$. These values are above the 95th percentiles determined in nonpregnant women $(0.37 \mathrm{~g} / \mathrm{L}$ and $1.85 \mathrm{mg} / \mathrm{L}$ for, respectively, $\mathrm{Cp}$ and $\mathrm{Cu}$ ).

\section{Psychiatric diagnosis and clinical data}

In patients diagnosed with alcohol abuse $(n=37)$, serum $\mathrm{Cp}$ (median 0.23, IQR $0.21-0.26 \mathrm{~g} / \mathrm{L}$ ) and $\mathrm{Cu}$ levels (median 1.15, IQR 0.97-1.31 mg/L) were slightly increased compared with patients with other diagnoses (Cp: median 0.21 , IQR $0.20-0.22 \mathrm{~g} / \mathrm{L}$; and $\mathrm{Cu}$ : median 1.01, IQR $0.87-1.15 \mathrm{mg} / \mathrm{L})(p<0.03$, Mann-Whitney test).

No association between serum $\mathrm{Cp}$ or $\mathrm{Cu}$ concentrations and psychiatric diagnosis was found in patients diagnosed with schizophrenia, bipolar disorders, depression and/or anxiety, behavioral or personality disorders, and other nonalcohol-related diseases ( $p>0.9$, KruskalWallis test) (Fig. 1a, b). Moreover, no association between serum $\mathrm{Cp}$ or $\mathrm{Cu}$ concentrations was found in patients with extrapyramidal symptoms $(n=5)(p>0.9$,
Mann-Whitney test). The concentrations found in patient with intellectual deficiency $(n=1)$ and in patient with kidney failure $(n=1)$ were above normal values.

\section{Treatment}

No association between serum $\mathrm{Cp}$ or $\mathrm{Cu}$ concentrations and treatment was found in patients under treatment with antipsychotics, antidepressants, and anticonvulsants $(p>0.9$, Kruskal-Wallis test).

\section{Critical and borderline values}

About $25 \%$ of patients $(n=67 / 269)$ showed serum Cp concentration $<0.18 \mathrm{~g} / \mathrm{L} ; 24 \%(n=66 / 269)$ showed $\mathrm{Cu}$ concentration $<0.88 \mathrm{mg} / \mathrm{L}$; and $19 \%(n=51 / 269)$ showed both decreased $\mathrm{Cp}$ and $\mathrm{Cu}$ concentrations. Two patients (with psychiatric diagnosis of schizophrenia and intellectual disability) showed critical serum $\mathrm{Cp}$ concentrations $(0.10 \mathrm{~g} / \mathrm{L})$; one of them also showed critical Cu concentration $(0.38 \mathrm{mg} / \mathrm{L})$. In these two patients, the urinary $\mathrm{Cu} / \mathrm{Cr}$ ratio were not increased $(6.3$ and $1.8 \mu \mathrm{g} / \mathrm{g}$, respectively, with a median value in a psychiatric population of $7.4 \mu \mathrm{g} / \mathrm{g})$.

\section{ATP7B mutation detection}

Fifty-one patients (15\%) showed both atypical psychiatric signs and $\mathrm{Cp} \leq 0.18 \mathrm{~g} / \mathrm{L}$ (borderline or critical values) and $\mathrm{Cu}$ concentration $\leq 0.88 \mathrm{mg} / \mathrm{L}$. None of them presented with the clinical signs of neurological WD. Among the 29 patients who gave their informed consent for genetic study, four presented with only one $A T P 7 B$ mutation (heterozygous state) identified by direct sequencing and MLPA analysis. Three different missense mutations were identified: p.His1069Gln, c.3207C >A (exon 14); p.Pro1379Ser, c.4135C $>\mathrm{T}$ (exon 21); and p.Thr1434Met, c.4301C $>\mathrm{T}$ (exon 21), (Table 1). These variants were classified as disease-causing mutations in the HUGO Wilson's disease database (http://www.uofa-medical-genetics.org/ wilson/index.php) and the Alamut or Polyphen sites.

The four cases were examined with careful attention. The urinary $\mathrm{Cu} / \mathrm{Cr}$ ratios were not increased except for one patient with a ratio value of $14.6 \mu \mathrm{g} / \mathrm{g}$, slightly above the 3rd quartile of the reference population $(12.1 \mu \mathrm{g} / \mathrm{g})$. Neurological examination did not reveal the usual pattern of WD (no dystonia, dysarthria, or other impairments). No Kayser-Fleischer rings were observed. Brain MRI was normal in three cases. The fourth case was a 35-year-old woman with a particular history of depression with suicidal attempt and cardiac arrest. Subsequently, she developed a syndrome of pure psychic akinesia with the usual Globus pallidus necrotic lesions shown at MRI [23, 24]. These patients receive a regular neurological and psychiatric assessment for four years. They did not exhibit other symptoms of WD. 

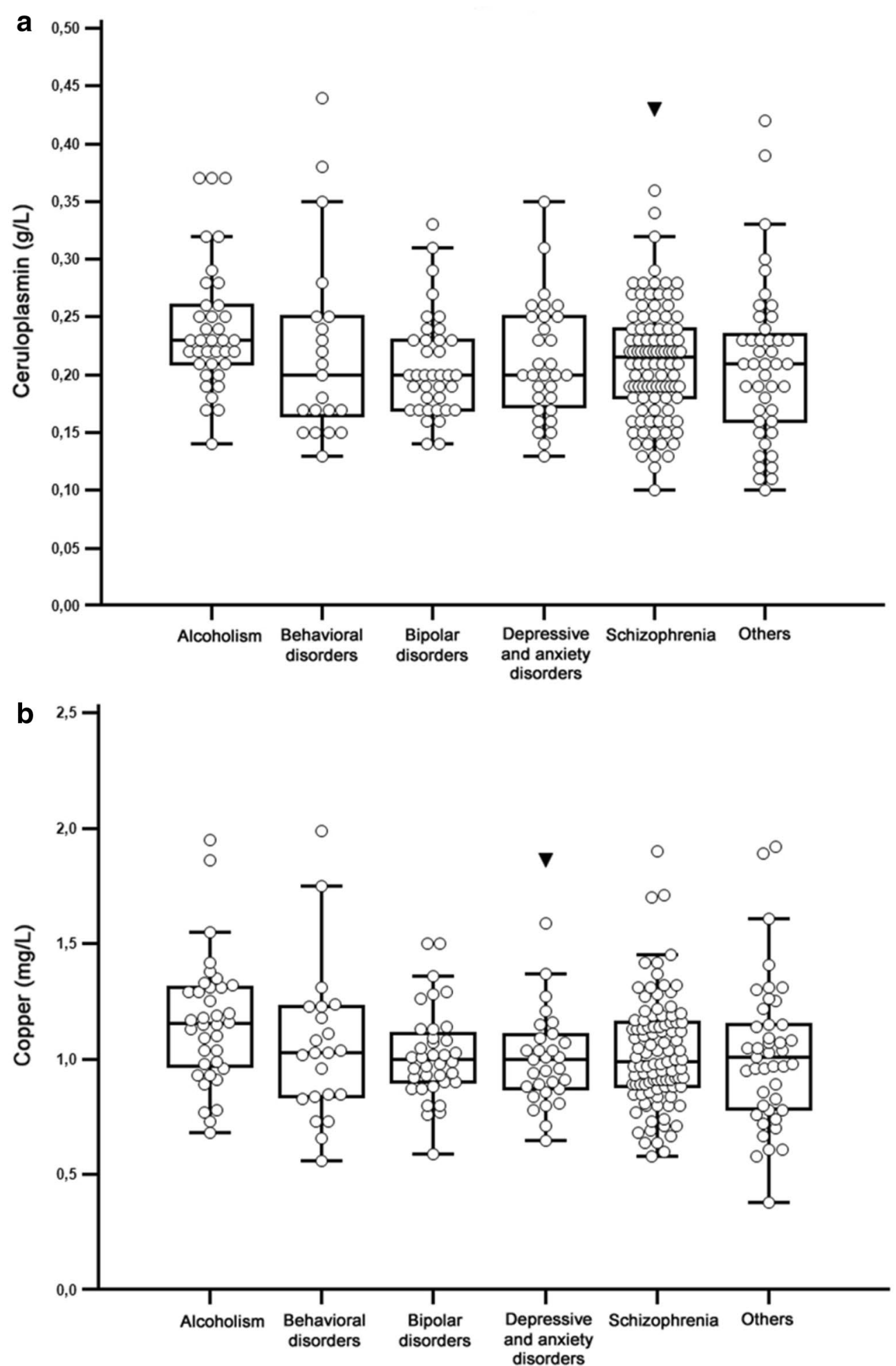

Fig. 1 Box plot graphs depicting serum $\mathrm{Cp}$ (a) and Cu concentrations (b) according to psychiatric diagnosis. The median serum Cp and Cu concentrations were not statistically different, except for alcoholism ( $p<0.05$ alcoholism vs. nonalcoholism) 
Table 1 Clinical and genetic study of psychiatric patients showing $\mathrm{Cp}<0.18 \mathrm{~g} / \mathrm{L}$ and serum Cu levels $<0.88 \mathrm{mg} / \mathrm{L}$

\begin{tabular}{|c|c|c|c|c|}
\hline Diagnosis & Associated symptoms & $C p^{a}(g / L)$ & Copper $^{\text {b }}$ (mg/L) & Mutations in $A T P 7 B$ gene \\
\hline Schizophrenia ( $n=13$ ) & Extrapyramidal syndrome $(n=3)$ & $0.10-0.17$ & $0.60-0.88$ & $\begin{array}{l}n=2 \text { heterozygous mutations } \\
\text { p.His1069GIn C.3207C>A (ex14) (Tanzi 1993) } \\
\quad \text { and p.Thr1434Met c.4301C>T (ex 21) [34] }\end{array}$ \\
\hline Bipolar disorders $(n=4)$ & Extrapyramidal syndrome $(n=1)$ & $0.15-0.17$ & $0.72-0.88$ & - \\
\hline $\operatorname{ASD}(n=3)$ & $\begin{array}{l}\text { Extrapyramidal syndrome }(n=1) \\
\text { Kidney failure }(n=1)\end{array}$ & $0.14-0.18$ & $0.65-0.86$ & - \\
\hline Personality disorders $(n=3)$ & & $0.13-0.15$ & $0.65-0.84$ & $\begin{array}{l}n=1 \\
\text { p.Pro1379Ser c.4135C>T (ex 21) [22] }\end{array}$ \\
\hline Neurological disorder $(n=2)$ & $\begin{array}{l}\text { Cerebral anoxia (MRI abnormalities in basal } \\
\text { ganglia) }(n=1)\end{array}$ & $0.12-0.16$ & $0.60-0.81$ & $\begin{array}{l}n=1 \\
\text { p.Thr1434Met c.4301C>T (ex 21) [34] }\end{array}$ \\
\hline Behavioral disorder $(n=1)$ & Mild intellectual deficiency $(n=1)$ & 0.15 & 0.80 & - \\
\hline Alcoholism $(n=1)$ & - & 0.15 & 0.78 & - \\
\hline Anorexia nervosa $(n=1)$ & - & 0.13 & 0.61 & - \\
\hline Depressive disorder $(n=1)$ & - & 0.17 & 0.87 & - \\
\hline
\end{tabular}

ASD Autism spectrum disorders

a $\mathrm{Cp}(\mathrm{g} / \mathrm{L})$, Normal values (NV) $0.18-0.32$, borderline values (BV) $0.10-0.17$, critical values (CV) $\leq 0.10$

b Copper (mg/L), NV 0.88-1.2, BV 0.50-0.87, CV $\leq 0.50$

\section{Serum ceruloplasmin and copper thresholds for WD screening in hospitalized patients with psychiatric disorders}

Using $\mathrm{Cp}$ and $\mathrm{Cu}$ below the normal values to identify possible WD clearly generates high levels of false positive results (assuming that no patients had WD, the false positive rate was $19 \%$ ).

\section{Discussion}

Establishing a diagnosis of WD is crucial since early detection and treatment may prevent disease progression and even reverse damage in some patients. Although the lifetime prevalence of psychiatric symptoms in WD patients is unclear, the estimated range is from 30 to $100 \%$ of symptomatic patients [25].

This study evaluated the feasibility and relevance of serum $\mathrm{Cp}$ and $\mathrm{Cu}$ level measures in a small sample size of hospitalized patients with psychiatric disorders $(n=269)$. Conventional WD testing is based on serum ceruloplasmin levels, but a normal ceruloplasmin level cannot exclude Wilson's disease [10, 26]. The serum copper, usually low, can be elevated as a result of release of free copper from a damaged liver.

Our main findings are the following: (1) a ratio of $1 / 5$ psychiatric patients with decreased $\mathrm{Cp}$ and $\mathrm{Cu}$ concentrations; and (2) the detection of several heterozygous $A T P 7 B$ mutations in patients with levels of ceruloplasmin and/or serum copper below the normal limits.

Given the small population of patients $(n=269)$, this study had too insufficient statistical power to draw any conclusions about the prevalence of WD in hospitalized patients with psychiatric disorders.

Our results are discussed below:

\section{Ceruloplasmin and serum copper values}

As shown in Table 1, psychiatric diagnosis had no significant effect on $\mathrm{Cp}$ and serum $\mathrm{Cu}$ levels since only alcoholic patients showed increased levels. This may be easily explained by the consequences of alcoholism on hepatic functions as previously described [27].

More interestingly, values below the normal ranges for ceruloplasmin and serum copper have been noted in 19\% of the psychiatric patients tested for WD. Thus, these criteria alone are not differentiating enough to establish a specific diagnosis of WD in patients with psychiatric disorders. Specific management is required to help psychiatrists with the early detection of WD in patients presenting isolated psychiatric symptoms without neurological and/or hepatic impairment. In such cases, exclusion of WD requires normal physical examination, brain MRI, and standard hepatic profile test.

A review of the literature on the psychiatric manifestations of WD reported that $\mathrm{Cp}$ was $<0.10 \mathrm{~g} / \mathrm{L}$ in most cases, except for a 15-year-old girl suffering from atypical depression and personality disorders. Her $\mathrm{Cp}$ was $0.24 \mathrm{~g} / \mathrm{L}$ with the increased hepatic enzymes, which led to Kaiser-Fleisher ring research and 24-h urine copper assay to confirm the diagnosis [28]. In a 38-year-old man with severe depression, Cp was $0.12 \mathrm{~g} / \mathrm{L}$ [29]. Decreased serum $\mathrm{Cu}(<0.60 \mathrm{mg} / \mathrm{L})$ and increased urinary copper levels were found in all patients $(>100 \mu \mathrm{g} / 24 \mathrm{~h})$.

Copper homeostasis in the CNS is securely synchronized, and perturbations in brain copper levels are known to underlie the mechanism of a wide spectrum of common neurodegenerative disorders [30]. Hence, it could be very promising to develop this approach in mental health. 


\section{Ceruloplasmin concentrations and pitfalls of interpretation}

The substantial intra-individual biological variability $(\mathrm{CVi})$ of serum $\mathrm{Cp}(\mathrm{CVi}=6.2 \%)$ may limit the clinical use of these data [31]. Thus, the accurate assessment of individual $\mathrm{Cp}$ concentrations in clinical practice requires two serum $\mathrm{Cp}$ measurements.

The standardization of $\mathrm{Cp}$ measurements remains an issue despite the availability of common reference material (ERM-DA470) [21, 32]. For instance, Infusino et al. [33] compared two methods for Cp measurement (Roche turbidimetric immunoassay vs. Beckman nephelometric immunoassay). Although a fairly good correlation was observed $(r=0.955)$, a highly significant proportional and constant bias was found: [Turbidimetric method $]=0.572[$ Nephelometric method $]+0.05 \mathrm{~g} / \mathrm{L}$. Consequently, clinicians should consider thresholds depending on the method used rather than adopting universal standards. Like other groups, we follow this rule in our laboratory.

\section{Molecular analysis of the ATP7B gene}

The study also showed that 4 of the 29 patients who gave their consent and were subject to molecular study $(\mathrm{Cp}<0.18 \mathrm{~g} / \mathrm{L})$ presented with heterozygous $A T P 7 B$ gene mutation. So far, such heterozygous carriage had been described as asymptomatic. Among these variants, two missense mutations were identified in the $3^{\prime}$ coding region (exon 21): p.Pro1379Ser and p.Thr1434Met, corresponding to the $\mathrm{C}$-terminus of ATP7B which is necessary for protein stability. Usually, the exon 21 is rarely mutated. Both variants were already reported by Cox [22] and Loudianos [34], respectively. They do not seem to affect copper transport function in the hepatocyte [35]. Further studies are needed to confirm these original data.

In previous articles, molecular data revealed over 520 disease-causing mutations and 136 polymorphisms in the $A T P 7 B$ gene along the whole length of the entire coding region (21 exons), as well as in promoter and intronic regions [22, 36-38]. These mutations may cause reduced copper incorporation into $\mathrm{Cp}$ and biliary excretion, leading to the accumulation of copper in the liver, brain, and cornea. In France, the mutations are mainly distributed on exons $2,3,5,6,7,8,10,12,13,14,15,16,17,18,19$, and 20, with a higher level of mutation observed on exons 14,8 , and 13 [22].

\section{Conclusions}

Considering the high rate of false positives in psychiatric population, the diagnosis of WD should be based on a combination of clinical and biological features. According to our study, specific management (e.g., in a reference center) is required when patients show threshold values, or when psychiatric and/or neurological and/or hepatic impairments are combined with borderline biological thresholds. Considering the literature data and this preliminary report, $\mathrm{Cp}$ levels $\leq 0.13 \mathrm{~g} / \mathrm{L}$ and serum $\mathrm{Cu}$ levels $\leq 0.60 \mathrm{mg} / \mathrm{L}$ seem to be the most accurate values to identify potential WD in psychiatric patients with normal hepatic and neurological profiles. However, this preliminary observation remains to be confirmed with further studies. Indeed, the exploration of copper metabolism in mental diseases should be of interest.

\section{Abbreviations \\ ATP7B: ATPase, $\mathrm{Cu}++$ transporting, beta polypeptide; CNS: central nervous system; Cp: ceruloplasmin; CV: coefficient of variation; ICD: international clas- sification of diseases; Serum Cu: serum copper; WD: Wilson's disease. \\ Authors' contributions \\ $M B, C D, A L$, and $D C$ designed the study. AP and $L R$ collected the clinical data. $E B$ performed the neurological assessment. OG performed the hepatic assess- ment. MB, FP, EB, and CD analyzed the data and wrote the paper. All authors read and approved the final manuscript.}

\section{Author details \\ ${ }^{1}$ GénoPsy, Center for the Detection and Management of Psychiatric Disorders of Genetic Origin, Pôle Ouest, Hôpital le Vinatier \& UMR 5229 (CNRS \& Lyon Univer- sity), 95 Bld Pinel, 69677 Bron cedex, France. ${ }^{2}$ Laboratory of Inherited Metabolic Diseases, Centre de Biologie Est, Hospices Civils de Lyon, Bron, France. ${ }^{3}$ National Reference Center for Wilson's disease, Hôpital Femme Mère Enfant, Hospices Civils de Lyon, Bron, France. ${ }^{4}$ Neurology Unit C, Cognitive Neurosciences Center, Hôpital Neurologique Pierre Wertheimer, Hospices Civils de Lyon; Claude Bernard-Lyon 1 University; CNRS UMR 5229, Bron, France. ${ }^{5}$ Hôpital Saint Jean de Dieu, Lyon, France. ${ }^{6}$ Hepato-Gastroenterology Department, Hôpital Edouard Herriot, Hos- pices Civils de Lyon, Lyon, France. ${ }^{7}$ Gastroenterology, Hepatology and Pediatric Nutrition Department, Hôpital Femme Mère Enfant, Hospices Civils de Lyon, Bron, France. ${ }^{8}$ Pharmaco-Toxicology, Biochemistry and Molecular Biology Unit, Hôpital} Édouard Herriot, Hospices Civils de Lyon, Lyon, France.

\section{Acknowledgements}

The authors would like to thank the Hospices Civils de Lyon (for Study management), Florence Apruzzese (for English editing assistance), le Conseil Scientifique et de la Recherche du Centre Hospitalier le Vinatier, and Julien Maurin and Guenaëlle Piguet-Lacroix (for technical assistance). MOPSY consortium was involved in the clinical and biological support of the study.

MOPSY Consortium (Maladie Organique et PSYchiatrie): Philippe Bernard, Fabienne Bourdoncle, Patrick Briant ${ }^{\wedge}$, Alain Fouilhoux, Sandrine Foullu, Marie-Hélène Girard-Madoux, Caroline Jeanpierre, Bernard Joli, Marianne Lemarié, Sophie Lonjaret, Jacques Marescaux, Philippe Paulino, Lionel Reinheimer, Jean-Maurice Tarissan

\section{Competing interests}

The authors declare that they have no competing interests.

\section{Consent}

Free, informed, written, specific and unambiguous consents were obtained for all participants. The study was approved by the competent French data protection authority (CPP Lyon Sud-Est IVNo 10/044, CNIL No DR-2011-470, Affsaps No B100832-40 and CCTIRS No 10.612 bis), in compliance with French legislation.

\section{Financial disclosure}

This study was financially supported by ADN association (France), Orphan Europe (France), and Swedish Orphan (Sweden), and Saint-Jean de Dieu Hospital (Promoter of the study). The funders had no role to play in the study design, data collection, and analysis, or in the decision to publish, or in the preparation of the manuscript. 


\section{Publisher's Note}

Springer Nature remains neutral with regard to jurisdictional claims in published maps and institutional affiliations.

Received: 24 May 2016 Accepted: 25 March 2017

Published online: 04 April 2017

\section{References}

1. Frydman M, Bonne-Tamir B, Farrer LA, Conneally PM, Magazanik A, Ashbel $\mathrm{S}$, et al. Assignment of the gene for Wilson disease to chromosome 13: linkage to esterase D locus. Proc Natl Acad Sci USA. 1985;82:1819-21.

2. Hahn SH. Population screening for Wilson's disease. Ann NY Acad Sci. 2014;1315:64-9.

3. Coffey AJ, Durkie M, Hague S, McLay K, Emmerson J, Lo C, et al. A genetic study of Wilson's disease in the United Kingdom. Brain. 2013;136:1476-87.

4. Chappuis P, Bost M, Misrahi M, Duclos-Vallée JC, Woimant F. La maladie de Wilson: aspects clinicobiologiques. Ann Biol Clin. 2005:63:457-66.

5. Michael L, Schilsky MD. Wilson disease: new insights into pathogenesis, diagnosis, and future therapy. Curr Gastroenterol Rep. 2005;7:26-31.

6. Weiss KH, Stremmel W. Clinical considerations for an effective medical therapy in Wilson's disease. Ann NY Acad Sci. 2014;1315:81-5.

7. Srinivas K, Sinha S, Taly AB, Prashanth LK, Arunodaya GR, Janardhana Reddy YC, et al. Dominant psychiatric manifestations in Wilson's disease: a diagnostic and therapeutic challenge. J Neurol Sci. 2008;266:104-8.

8. Silva F, Nobre S, Campos AP, Vasconcelos M, Goncalves I. Behavioral and psychiatric disorders in paediatric Wilson's disease. BMC Case Rep. 2011;4:2011.

9. Steindl P, Ferenci P, Dienes HP, Grimm G, Pabinger I, Madl C, et al. Wilson's disease in patients presenting with liver disease: a diagnostic challenge. Gastroenterology. 1997:113:212-8.

10. Zimbrean PC, Schilsky ML. Psychiatric aspects of Wilson disease: a review. Gen Hosp Psychiatry. 2014;36:53-62

11. Eggers B, Hermann W, Barthel H, Sabri O, Wagner A, Hesse S. The degree of depression in Hamilton rating scale is correlated with the density of presynaptic serotonin transporters in 23 patients with Wilson's disease. J Neurol. 2003;250:576-80.

12. Bidaki R, Zarei M, Mirhosseini SM, Moghadami S, Hejrati M, Kohnavard M, Shariati B. Mismanagement of Wilson's disease as psychotic disorder. Adv Biomed Res. 2012;2012(1):61.

13. Sedel F, Baumann N, Turpin JC, Lyon-Caen O, Saudubray JM, Cohen D. Psychiatric manifestations revealing inborn errors of metabolism in adolescents and adults. J Inherit Metab Dis. 2007;2007(30):631-41.

14. Demily C, Sedel F. Psychiatric presentation of treatable hereditary metabolic disorders in adults. Ann Gen Psychiatry. 2014;24(13):27. doi:10.1186/ s12991-014-0027.

15. Ferenci P, Caca K, Loudianos G, Mieli-Vergani G, Tanner S, Sternlieb I. Diagnosis and phenotypic classification of Wilson disease. Liver Int. 2003:23:139-42.

16. Cauza E, Maier-Dobersberger T, Polli C, Kaserer K, Kramer L, Frenci P. Screening for Wilson's disease in patients with liver diseases by serum ceruloplasmin. J Hepatol. 1997;27:358-62.

17. LaRusso NF, Summerskill WH, McCall JT. Abnormalities of chemical tests for copper metabolism in chronic active liver diseases: differentiation from Wilson's disease. Gastroenterology. 1976;70:653-5.

18. Lecrubier $Y$, Sheehan D, Weiller E, Amorim P, Bonora I, Sheehan K, et al. The M.I.N.I. International Neuropsychiatric Interview (M.I.N.I.) A Short Diagnostic Structured Interview: reliability and Validity According to the CIDI. Eur Psychiatry. 1997;12:224-31.

19. Twomey PJ, Viljoen A, House IM, Reynolds TM, Wierzbicki AS. Relationship between serum copper, ceruloplasmin and non-ceruloplasmin-bound in routine clinical practice. Clin Chem. 2005;51:1558-9.

20. Mak CM, Lam CW. Diagnosis of Wilson's disease: a comprehensive review. Crit Rev Clin Lab Sci. 2008:45:263-90.
21. Zegers I, Beetham R, Keller T, Sheldon J, Bullock D, MacKenzie F, et al. The importance of commutability of reference materials used as calibrators: the example of ceruloplasmin. Clin Chem. 2013;59:1322-9.

22. Cox DW, Prat L, Walshe JM, Heathcote J, Gaffney D. Twenty-four novel mutations in Wilson disease patients of predominantly European ancestry. Hum Mut. 2005;26:280-7.

23. Laplane D, Baulac M, Widlöcher D, Dubois B. Pure psychic akinesia with bilateral lesions of basal ganglia. J Neurol Neurosurg Psychiatry. 1984:47:377-85.

24. Laplane D, Dubois B. Auto-Activation deficit: a basal ganglia related syndrome. Mov Disord. 2001;16:810-4.

25. Carta MG, Sorbello O, Moro MF, Bhat KM, Demelia E, Serra A, et al. Bipolar disorders and Wilson's disease. BMC Psychiatry. 2012;12:52-9.

26. Hancu A, Mihai MC, Axelerad AD. Wilson's disease: a challenging diagnosis Clinical manifestations and diagnosis procedures in 12 patients. Rev Med Chir Soc Med Nat. 2011;115:58-63.

27. Wu CT, Lee JN, Shen WW, Lee SL. Serum zinc, copper and ceruloplasmin levels in male alcoholics. Biol Psychiatry. 1984;19:1333-8.

28. Frank E, Crumley MD. Pitfalls of diagnosis in the early stages of Wilson's disease. J Am Acad Child Adolesc Psychiatry. 1990;29:470-1.

29. Keller R, Torta R, Lagget M, Crasto S, Bergamasco B. Psychiatric symptoms as late onset of Wilson's disease: neuroradiological findings, clinical features and treatment. Ital J Neurol Sci. 1999;20:49-54.

30. Brewer GJ. Divalent Copper as a major triggering agent in alzheimer's disease. J Alzheimers Dis. 2015;25:593-604

31. Braga F. SzőkeD, Valente C, Panteghini M. Biologic variation of copper, ceruloplasmin and copper/ceruloplasmin ratio (Cu:Cp) in serum. Clin Chim Acta. 2013;415:295-6.

32. Merlini G, Blirup-Jensen S, Johnson AM, Sheldon J, Zegers I. Standardizing plasma protein measurements worldwide: a challenging enterprise. Clin Chem Lab Med. 2010:48:1567-75.

33. Infusino I, Valente C, Dolci A, Panteghini M. Standardization of ceruloplasmin measurements is still an issue despite the availability of a common reference material. Anal Bioanal Chem. 2010;397:521-5.

34. Loudianos G, Dessi V, Lovicu M, Angius A, Altuntas B, Giacchino R, et al. Mutation analysis in patients of Mediterranean descent with Wilson disease: identification of 19 novel mutations. J Med Genet. 1999:1999(36):833-6.

35. Hsi G, Cullen LM, Moira Glerum D, Cox DW. Functional assessment of the carboxy-terminus of the Wilson disease-transporting ATPase, ATP7B. Genomics. 2004;83:473-81.

36. Figus A, Angius A, Loudianos G, Bertini C, Dessi V, Loi A, et al. Molecular pathology and haplotypes analysis in Mediterranean populations. Am J Hum Genet. 1995:57:1318-24.

37. Loudianos G, Dessi V, Lovicu M. Haplotype and mutation analysis in Greek patients with Wilson disease. Eur J Hum Gen. 1998;6:487-91.

38. Bost M, Piguet-Lacroix G, Parant F, Wilson CM. Molecular analysis of Wilson patients: direct sequencing and MLPA analysis in the ATP7B gene and Atox1 and COMMD1 gene analysis. J Trace Elem Med Biol. 2012;26:97-101.

\section{Submit your next manuscript to BioMed Central and we will help you at every step:}

- We accept pre-submission inquiries

- Our selector tool helps you to find the most relevant journal

- We provide round the clock customer support

- Convenient online submission

- Thorough peer review

- Inclusion in PubMed and all major indexing services

- Maximum visibility for your research

Submit your manuscript at www.biomedcentral.com/submit
C BioMed Central 